\title{
Turkey's Aquaculture Potential and Developments in the Fish Feed Sector
}

\section{Aysun KOP*}

Department of Aquaculture, Faculty of Fisheries, Ege University, Turkey

*Corresponding author: Aysun KOP, Department of Aquaculture, Faculty of Fisheries, Ege University, Bornova/Izmir, Turkey, Tel: +902323113842; Email:

\section{Mini Review}

Volume 2 Issue 4

Received Date: May 21, 2018

Published Date: May 30, 2018 yayskop@mail.com

\section{Abstract}

In this study, Turkey's aquaculture potential was investigated. Aquaculture studies started in fresh water in 1970s. Production of sea fish was started in 1985. The amount of aquaculture in 2016 is 253,395 tons. 59. 9\% of this is from sea fish and 40. 1\% from freshwater fish. Turkey has exported 145469 tons of fish in 2016 and has achieved \$ 870 million profit as of 2017.

Keyword: Turkey; Aquaculture potential; Sea fish; Export amount

\section{Introduction}

Turkey has a coastline of $8,333 \mathrm{~km}$ long and is surrounded by sea on three sides. In addition, there are 33 rivers, more than 120 natural lakes, 706 dam reservoirs [1]. The Black Sea in the north of the country, the Aegean Sea in the west, and the Mediterranean in the south. The total surface area of marine and freshwater resources in Turkey is approximately 25 million hectares.

Aquaculture in Turkey is a rapidly evolving industry. The first trout farm was established in the 1970s, while the sea bass and sea bream facility was established in 1985. According to the values of the year 2018, there are a total of 2308 enterprises, 1881 in the inland waters and 427 in the seas [2].

The total production of fish for the year 2016 is 588,715 tons [3] of this, 335.320 tons are obtained from fishing, while 253.395 tons are obtained from aquaculture. 151.794 tons (59.9\%) of aquaculture amounts comes from the sea and 101.601 (40.1\%) from the inland water. The most common types of fish produced are Trout (Oncorhynchus mykiss) 107,013 tons, Sea bream (Sparusaurata) 58,254 tons and Sea bass (Dicentrarchuslabrax) 80,847 tons.

Turkey's aquaculture fastly developed until 2000. However, a falling was observed in current output in the early 2000s. The severe economic crisis that Turkey experienced played an important role here. With aquaculture, output tended to increase in 2003. Some factors such as the recovery of economy, Turkey's progress in $\mathrm{AB}$ membership and financial aid of the state to the sector affected the growth. Since 2013, Turkey has taken the first place in salmon production and the third place in bream and bass production among European countries. Therefore one out of every three fish commercialized to European countries springs from Turkey.

Turkey's export of aquatic products sector tends to go up constantly and it has been 870 million dollars in 2017 . Although Turkey's exports of fishery products 14533 


\section{International Journal of Oceanography \& Aquaculture}

tons in 2000, this amount increased to 145469 tonnes in 2016.

The majority of the fish species produced are carnivorous. Animal protein sources constitute $60-80 \%$ of the mixed feed compositions of carnivorous fish, which prefer raw materials of animal origin in their feed. The most important part of unit fish production cost is feed with $30-70 \%$. Feed production first began with the establishment of a feed mill in the year 1955 by the private sector in Turkey. Then in 1956 Yem Sanayi Türk AS was established as a state enterprise and continued its activities until 1996. Turkey produces 3533 tons of feed in 1959 reached about 13.5 million tons in 2017. The feeds used in the aquaculture sector were considered as "fish feed" for the first time in 1999 with 38. 415 tons, while it was considered in other feed groups until 1998. Initial studies conducted relating to fish feed production in Turkey was initiated with press pellet systems in 19861987, feeds were predominantly for produced carp and trout, and that fish feed production with extrusion system was initiated in 1998. Turkey's fish feed production quantity is about 460 000tonnes in 2017. Fish feed production is carried out in 25 plants approximately satisfying the need of aquaculture sector of our country. There are $60 \%$ of plants producing fish feed in Aegean Region (İzmir 7; Aydın 3; Muğla 4; Afyon 1), 12\% in Black Sea Region (Trabzon 1; Sinop 1; Samsun 1), 8\% in Marmara Region (Tekirdağ 1; Kırklareli 1), 4\% in Mediterrenean Region (Antalya 1), 8\% in Southeastern Anatolia Region (Gaziantep 1; Kahramanmaraş 1), 4\% in Eastern Anatolia Region (Erzurum 1) and 4\% in Central Anatolia Region (Kayseri 1). It is seen that fish feed production plants in our country are predominantly in Aegean Region. The main reason for this may be considered as more common presence of aquaculture in this region. Majority of feed-producing plants prefer extruder feed production technology. It is also seen that feed plants use particularly expander and pellet press systems collectively. This kind of application was determined as 5\%, more common in regions other than Aegean Region. All fishfeed production plants are private sector businesses and majority of these businesses are constructions having integrating features such as aquaculture, processing, packaging, importation and exportation. It is see that the fish feed industry develops rapidly in parallel as well as the development of aquaculture in Turkey.

There are 30 raw material and additives suppliers in Turkey in accordance with regions. Supplier companies are predominantly in Aegean Region and there is a similar appearance for additives as well. All of these companies are within Turkey and $80 \%$ of them worked in cooperation with foreign countries. Also, it is determined that $5 \%$ of supplied raw material was organic-certified [4].

There are currently totally 18 feed production machines, feed provision systems, plant installation and software suppliers in Turkey, 8 of these businesses are in Aegean Region, 3 in Marmara Region, one in Central Region and one in Southeastern Anatolia Region. 25\% of these support machine and plant installation with domestic production, and the countries supporting foreign companies having suppliers in Turkey are respectively; Norway, Denmark, USA, Germany and China [4].

Turkey has a rapidly growing aquaculture, as well as an aquafeed industry. Fish feed industry has 15 fish feed plant in 2008 and it increased to 25 in 2017. This number will reach 30 and above in next few years. Turkey ranks first relating to fish feed production among all Mediterranean Region countries.

\section{Compound Fish Feed Production Problems Faced by Turkey's}

Fish meal is the first raw material of animal origin used in the production of fish feeds. Due to the inadequate production of fish meal in our country and the low quality of the produced fish meal, $70 \%$ of it is supplied from abroad.

A great part of the raw materials such as soybean, soybean meal, full fat soybean meal, corn and wheat gluten and corn meal are imported from the main herbal products used in the production of compound fish feeds.

The use of feed additives is widespread in our country but very little in production. These substances are generally supplied from abroad as pure, concentrated or premixed largely by companies engaged in mixed feed production or by companies engaged in the trade of feed additives.

Another problem of compound feed industry in Turkey is also pricing and marketing. The excessive increase in compound feed prices is the biggest obstacle to the development of this industry, as the prices of feedstuffs in our country are higher than world prices, the operating capital and stocks are inadequate, and pricing cannot be done according to quality. In addition, unregistered sales 


\section{International Journal of Oceanography \& Aquaculture}

are a major issue for marketing, which is important for the market.

As a result; adequate and cheap labor power assets, the presence of a suitable background for the production of fish larvae and juvenile, the development of compound fish feed technology, the presence of feed mills, sufficient water supply and knowledge, the presence of modern processing and packaging facilities, the existence of the quality control and residue monitoring program and system, the existence of educational and research institutions, rich flora or fauna biodiversity and abundance of economic fish species, rapid identification and implementation of EU environmental and fisheries legislation, implementation of environmental management plans in some farming and processing facilities of a national monitoring program, although it is not carried out, are powerful aspects of aquaculture in Turkey. High production costs (energy, feed, rent, etc. ), inadequate fish consumption habit, rental fees of production areas and high rate of increase of rent, inadequacy of bivalve aquaculture and negative media pressure on farming, are the main weaknesses of Turkey. Rapid return of investment, the presence of underutilized water resources and potential abundance, cheaper labor force, high export potential, demand for white and omega3 rich meat, market presence in the Middle East and other
Turkic republics, possibility of alternative breeding opportunities in terms of biodiversity, the increase in international funding for environmental protection given to Turkey, ecological production practices began to be adopted in Turkey are the greatest opportunities in aquaculture [5].

\section{References}

1. (2014) TGDSHW (The General Directorate of State Hydraulic Works) Land and Water Resources.

2. (2018) RTMFAL (Republic of Turkey Ministry of Food, Agriculture and Livestock) Fisheries Statistics.

3. (2018) TSI (Turkey Statistical Institute) Fishery Statistics.

4. Korkut AY, Kop A, Saygi H, Göktepe C, Yedek Y, et al. (2017) General Evaluation of Fish Feed Production In Turkey. Turkish Journal of Fisheries and Aquatic Sciences 17: 223-229

5. Yavuzcan H, Pulatsü S, Demir N, Kırkağaç M, Bekcan S, et al. (2010) Türkiye' de sürdürülebilir su ürünleri yetiştiriciliği. TMMOB Ziraat Mühendisliği VII. Teknik Kongresi, Bildiriler Kitabı 2: 767-789. 